\title{
Gestational diabetes: a risk of puerperal hypovitaminosis A?
}

\author{
FERNANDA B.S. RESENDE ${ }^{1}$, LARISSA Q. DE LIRA ${ }^{2}$, \\ EVELLYN C. GRILO ${ }^{2}$, MAYARA S.R. LIMA ${ }^{2}$ and ROBERTO DIMENSTEIN ${ }^{2}$ \\ ${ }^{1}$ Secretaria Estadual de Saúde do Rio Grande do Norte, Av. Deodoro da Fonseca, 730, \\ Ed. do INAMPS, $8^{\circ}$ andar, Bairro Cidade Alta, 59020-600 Natal, RN, Brasil \\ ${ }^{2}$ Departamento de Bioquímica, Universidade Federal do Rio Grande do Norte, \\ Av. Senador Salgado Filho, 3000, Bairro Lagoa Nova, 59072-970 Natal, RN, Brasil \\ Manuscript received on April 9, 2014; accepted for publication on November 25, 2014
}

\begin{abstract}
The influence of gestational diabetes on vitamin A deficiency in lactating women and, consequently, in their newborn has been verified through a cross-sectional case-control study conducted with volunteer puerperal women. The control group consisted of healthy women and the test group was composed of women with gestational diabetes. One hundred and seven women were recruited, corresponding to 71 controls and 36 cases. Personal, gestational and newborn data were collected directly from medical records during hospitalization. The retinol was determined in maternal colostrum and serum by High Performance Liquid Chromatography. Postpartum women with gestational diabetes were older, had more children and a higher prevalence of cesarean delivery. No difference was found in retinol concentration in maternal milk and serum between the groups. However, it was observed that $16.7 \%$ had vitamin A deficiency in the group of patients with diabetes and only $4.1 \%$ had such deficiency in the control group. Although no difference was found in colostrum and serum retinol concentration between women with and without gestational diabetes, the individual analysis shows that those with diabetes are at higher risk of being vitamin A deficient.
\end{abstract}

Key words: colostrum, Gestational diabetes, HPLC, Hypovitaminosis A, Postpartum.

\section{INTRODUCTION}

Micronutrient deficiencies are common in developing countries and are mainly related to malnutrition, diet quality, bioavailability or the compromised health of an individual, as in infections (Ramakrishnan 2002). Hypovitaminosis A is a most alarming public health issue worldwide, especially in groups with increased physiological needs, such as women at reproductive age and children (Suskind 2009). The term Vitamin A designates

Correspondence to: Evellyn Câmara Grilo

E-mail: evellyn-cg@hotmail.com any compound having biological activity of retinol, which has the function of helping with growth, cell differentiation and proliferation, reproduction, maintaining the integrity of the immune system and function of participation in the visual cycle, among others (Debier and Larondelle 2005).

Vitamin A is obtained from dietary sources as retinol esters and goes along the chylomicrons to the liver, where they are captured by hepatic parenchymal cells (Harrison 2005). Part of retinol esters are readily hydrolyzed to retinol, which binds to retinol binding protein (RBP), a specific protein of plasmatic 
transport, which carries the retinol from the liver to the target cells (Basu and Basualdo 1997). The RBPretinol complex is captured by a variety of cells that bear specific receptors for RBP on their surface, and their plasma levels correlate positively with the retinol levels (Rhee and Plutzky 2012). In appropriate nutrient conditions, $90 \%$ of circulating RBP4 is connected to retinol (RBP4 concentration in adults is $2-3 \mu \mathrm{M}$ ) (Bellovino et al. 2003). During vitamin A metabolism, the digestion and intestinal absorption of vitamin A seems not to be affected in individuals with diabetes, since studies have demonstrated the relationship among retinol and/or RBP and diabetes (Rhee and Plutzky 2012, Erikstrup et al. 2009), as well as with gestational diabetes (Chan et al. 2007).

Gestational Diabetes Mellitus (GDM) is characterized by a decrease in glucose tolerance, of variable magnitude, first diagnosed during pregnancy and may or may not persist after giving birth (Metzger et al. 2007). Similar to Diabetes Mellitus type 2, GDM is associated with both insulin resistance and the decreased function of $\beta$-cells, which are unable to meet the increasing organic needs for insulin (Krzyzanowska et al. 2008). It occurs in $1-14 \%$ of all pregnancies depending on the population studied, and it is associated with the increased perinatal morbidity and mortality (Sociedade Brasileira de Diabetes 2009).

Pregnancy in women with diabetes is associated with the increased risk for both the fetus and the mother. There is an increased prevalence of congenital anomalies and spontaneous abortions. Furthermore, the fetus may have macrosomia, hypoglycemia, hyperbilirubinaemia, hypocalcaemia, polycythaemia and respiratory distress syndrome (Golbert and Campos 2008).

Literature shows conflicting information on concentrations of retinol and RBP4 serum in women affected by gestational diabetes, since some studies with pregnant women present such reductions, while others did not. Furthermore, information on puerperal women are scarce.
According to Lira and Dimenstein (2010), concerning the knowledge about the relevant physiological roles of Vitamin A and the factors that influence its concentrations, the need of monitoring this vitamin during pregnancy is clear, especially if accompanied by diabetes mellitus, in order to prevent installation of other pathological complications for the mother and her infant.

Given the importance of vitamin A to both the mother and the child, this study aimed at measuring the concentration of retinol in milk and serum of puerperal women with diabetes, in order to identify if gestational diabetes is at a risk factor for hypovitaminosis $\mathrm{A}$ in this group.

\section{MATERIALS AND METHODS}

A case-control of the transversal type, comprised of volunteer puerperal women met in Januário Cicco Maternity School in Natal, Rio Grande do Norte, Brazil. Such maternity school is acknowledged as being an institution of reference for high-risk births, comprising cases of gestational diabetes. The study took place between August 2011 and August 2012.

The women were organized into a control group, composed by women without gestational diabetes, and a case group, comprised of mothers who were diagnosed with diabetes during pregnancy. Such diagnosis was made following the criteria of the Ministry of Health, according to which gestational diabetes is confirmed if the pregnant woman performs two fasting blood glucose tests and both have result $\geq 126 \mathrm{mg} / \mathrm{dL}$. Women with positive screening were subjected to confirmation of diagnosis by means of the oral glucose tolerance test (Ministério da Saúde 2010).

Therefore, in order to calculate the sample, Power Analysis was initially used. Parameters utilized were size of effect of $\mathrm{d}=0.70$ for t-test, and $\mathrm{OR}=2.5$ for logistic regression, $\alpha=0.05$ and test power of (1- $\beta$ ) 0.95 , resulting in a minimum sample size of 110 pacients puerperal women. Given that $14 \%$ of all births that occur at the studied 
maternity are of women with gestational diabetes, a minimum sample size of 13 subjects in case group it is recommended.

The recruiting period lasted one year (from August 2011 to August 2012), resulting in 109 patients. Two of them were excluded of analysis due to missing data. Thus, the sample $(n=107)$ was composed of 71 controls and 36 cases. This sample size represented, for t-test and logistic regression, respectively, an achieved power of 0.83 and 0.94 , both adequate according to Cohen (1988).

Women older than 40 years, with associated diseases (cancer, heart diseases, diseases of the gastrointestinal tract, hepatic impairment and infectious diseases such as syphilis and HIV), multiple conceptus, conceptus with malformation and who used vitamin supplements containing vitamin A during pregnancy, were excluded from the study.

After explaining the research objectives and obtaining the authorization through the Informed Consent Form (ICF), documentation approved by the Committee of Ethics in Research of the University Hospital Onofre Lopes of UFRN (Protocol No. 325 - 09), a survey for obtaining information such as personal data, prenatal and childbirth was undertaken. Data from prenatal and childbirth information were collected from medical records of each puerperal woman.

After these were completed, $5 \mathrm{~mL}$ of blood was collected from the patient, early in the morning, after an overnight fast of at least 8 hours, and stored in a polypropylene tube protected from light. Then $3 \mathrm{~mL}$ of colostrum was collected from the patient. The samples were also stored under the same conditions, and transported to the laboratory in Department of Biochemistry of the Center for Biosciences (UFRN). The aliquots of blood were centrifuged for 5 minutes $(500 \mathrm{xg}$ ) for separation and removal of serum, and then the collected breast milk was taken to a water bath at $37{ }^{\circ} \mathrm{C}$ and stirred for homogenization, where $500 \mu \mathrm{L}$ was separated and stored at $-20{ }^{\circ} \mathrm{C}$ for further analysis. The remaining samples were quantified and stored under the same conditions.

EXTRACTION OF RETINOL FROM THE SAMPLES

The breast milk retinol was extracted according to Giuliano et al. (1992), with adaptations. The method consisted of an alkaline hydrolysis and protein denaturation, using the potassium hydroxide (50\%) and ethyl alcohol $95 \%$ as reactants, respectively. The proportion of reactants is $1: 1$ starting with $500 \mu \mathrm{L}$ of milk. Then the solutions were homogenized for 1 minute and subjected to heating in a water bath under stirring at $60{ }^{\circ} \mathrm{C}$ for 1 hour. The hexane was used as the extraction reagent, being added to the samples $(2 \mathrm{~mL})$, subjected to agitation for 1 minute and centrifuged at $4000 \mathrm{rpm}$ for 10 minutes. After the separation of phases, the hexane layer was removed to another tube. Such process occurred three times, resulting in approximately $6 \mathrm{~mL}$.

An aliquot of $3 \mathrm{ml}$ of hexane phase was evaporated under a nitrogen atmosphere in a water bath at $37^{\circ} \mathrm{C}$. The extracts were dissolved in $500 \mu \mathrm{l}$ of absolute ethanol in degree of purity for Highperformance Liquid Chromatography (HPLC) and centrifuged for 1 minute.

The serum retinol was extracted from $1 \mathrm{~mL}$ sample by using the same procedure of the milk starting, except the saponification step. The concentration of retinol in serum and milk were expressed in $\mu \mathrm{mol} / \mathrm{L}$. The maternal vitamin A deficiency was defined when the concentrations found in serum were of $\leq 0.7 \mu \mathrm{mol} / \mathrm{L}(\leq 20 \mu \mathrm{g} /$ $\mathrm{dL})$ and in milk, $\leq 1.4 \mu \mathrm{mol} / \mathrm{L}(\leq 40 \mu \mathrm{g} / \mathrm{dL}$ ) (World Health Organization 1996).

RETINOL ANALYSIS

The retinol concentration was determined by Highperformance Liquid Chromatography under the following conditions: Chromatograph LC-10 AD Shimadzu Liquid Chromatography; Detector SPD10 A Shimadzu UV-VIS; Integrator Chromatopac 
C-R6A Shimadzu; Column Shimpack CLCODS(M) $4.6 \mathrm{~mm} \quad$ x $25 \mathrm{~cm}$; Mobile Phase Methanol $100 \%$ and flow rate of $1.0 \mathrm{~mL} / \mathrm{min}$. The identification and quantification of retinol in the samples were established by comparison with the retention time and the area of the respective standard. The concentration of the standard was confirmed by specific extinction coefficient ( $\varepsilon 1 \%$, $1 \mathrm{~cm}=1850)$ in absolute ethanol and a wave length of $325 \mathrm{~nm}$ (Nierenberg and Nann 1992).

\section{LiNEARITY, ACCURACY AND PRECISION OF THE METHOD}

The calibration curve (linearity) was made using, as a standard, all-trans retinol (Sigma) at different concentrations of $1 \mathrm{ng} / 20 \mu \mathrm{L}$ to $128 \mathrm{ng} / 20 \mu \mathrm{L}$, consisting of eight points. The equation of the line obtained by linear regression (concentrations of the standards versus their respective fields) was $\mathrm{y}=$ $6877.8 \mathrm{x}+1812.4$. The linearity coefficient was $\mathrm{R}^{2}$ $=0.9997$ (Fig. 1).

The accuracy was verified according to the recovery test. After this simulation, the results showed that the extraction of retinol was effective since it achieved total recovery of the internal standard. The precision of the method was tested by repetitiveness in which three samples extracted and dissolved in absolute ethanol were applied on three alternate days. The coefficient of variation was below $4 \%$.

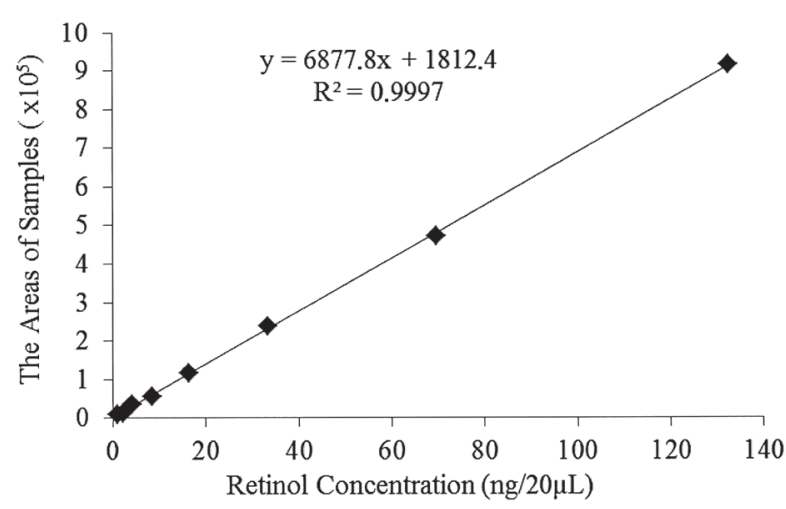

Figure 1 - Calibration curve pattern in different concentrations, demonstrating the equation of the line and linear regression coefficient $\left(\mathrm{R}^{2}\right)$.
STATISTICAL ANALYSIS

Statistical analysis was performed using the SPSS software. Retinol values were expressed as mean and standard deviation, and hypovitaminosis A in percentage. Kolmogorov-Smirnov test of normality showed that data were parametric $(p>$ 0.05). Therefore, differences between control and cases were checked through the use of independent samples t-test. Logistic regression was used to calculate crude odds ratio (OR) of occurrence of hypovitaminosis A among groups. Differences were considered significant at $\mathrm{p}<0.05$.

\section{RESULTS}

The study included 71 controls and 36 cases, and their characteristics as described in Table I. The weight of the newborn was also recorded, with an average of $3239.7 \pm 541.9 \mathrm{~g}$ among controls and $3403.9 \pm 909.3 \mathrm{~g}$ among cases group and did not differ statistically. With regards to biochemical tests, it appears that fasting glucose of controls showed an average of $4.18 \pm 0.65 \mathrm{mmol} / \mathrm{L}$, and for the cases, the average $6.9 \pm 2.4 \mathrm{mmol} / \mathrm{L}$. The rates for hemoglobin were $137 \pm 119 \mathrm{~g} / \mathrm{L}$ and $162 \pm 190 \mathrm{~g} / \mathrm{L}$, respectively, with no statistically significant difference.

TABLE I

Maternal and childbirth characteristics of the population studied.

\begin{tabular}{lcc}
\hline \multicolumn{1}{c}{ Variables } & $\begin{array}{c}\text { Control group } \\
(\mathbf{n}=\mathbf{7 1})\end{array}$ & $\begin{array}{c}\text { Cases group } \\
(\mathbf{n}=\mathbf{3 6})\end{array}$ \\
\hline Age (average in years) & $26.5 \pm 13.5$ & $31.5 \pm 4.9$ \\
Parity (\% over 2 children) & 48 & 75 \\
Cesarean child birth $(\%)$ & 48 & 78 \\
$\begin{array}{l}\text { Weight gain during } \\
\text { pregnancy }(\mathrm{Kg})\end{array}$ & $10.2 \pm 5.3$ & $11.4 \pm 5.4$ \\
Pre-pregnancy BMI $\left(\mathrm{Kg} / \mathrm{m}^{2}\right)$ & $23.4 \pm 4.4$ & $30.3 \pm 6.6$ \\
Pregnancy BMI $\left(\mathrm{Kg} / \mathrm{m}^{2}\right)$ & $27.7 \pm 4.4$ & $32.8 \pm 6.8$ \\
\hline
\end{tabular}

The colostrum retinol showed an average of $4.6 \pm 1.9 \mu \mathrm{mol} / \mathrm{L}$ for the controls and $4.4 \pm 1.5$ $\mu \mathrm{mol} / \mathrm{L}$ for the cases. Regarding the maternal 
serum, controls achieved an average of $1.4 \pm 0.4$ $\mu \mathrm{mol} / \mathrm{L}$ and the cases achieved an average of 1.2 $\pm 0.5 \mu \mathrm{mol} / \mathrm{L}$. The assessment of mean retinol concentrations in maternal milk and serum indicate adequate nutritional status of vitamin $\mathrm{A}$ in studied groups. Our results did not show a significant difference of retinol concentration in milk $(\mathrm{p}=$ $0.57)$ or serum $(\mathrm{p}=0.39)$.

Although no significant difference between the means was found, the individual analysis shows that in maternal serum a hypovitaminosis
A percentage of $4.1 \%$ for controls and $16.7 \%$ for the cases it was observed. Such condition was not observed in colostrum retinol (Fig. 2).

By analyzing the probability of retinol concentration in breast milk being below $1.4 \mu \mathrm{mol} / \mathrm{L}$ (cutting point), was the same for both controls and cases. However, probability of occurrence of vitamin A deficiency in maternal serum below 0.7 $\mu \mathrm{mol} / \mathrm{L}$ was 4.53 times higher to GDM women than healthy puerperal women (Crude Odds Ratio $(95 \% \mathrm{CI})=4.53(1.06-19.34) \mathrm{p}<0.05)$.

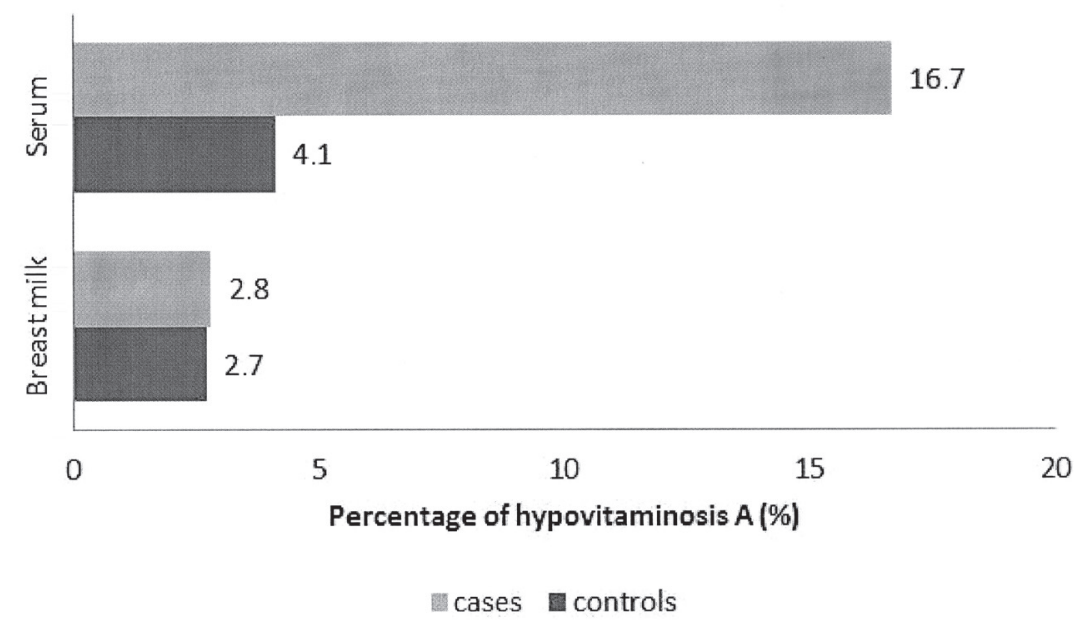

Figure 2 - Percentage of hypovitaminosis A in maternal serum and breast milk in studied groups.

\section{DISCUSSION}

The Ministry of Health describes in its technical manual (Ministério da Saúde 2010) that the age over 35 is a risk factor for gestational diabetes, combined with maternal body mass index (BMI) $\geq$ $24 \mathrm{~kg} / \mathrm{m}^{2}$ (overweight and obesity), macrosomy in previous pregnancy, excessive weight gain during pregnancy, among other factors.

Regarding the biochemical analysis, the colostrum retinol found for healthy puerperal women was similar to those found in the literature (Ribeiro et al. 2009, Szlagatys-Sidorkiewicz et al. 2012). However, there are not studies with the same characteristics in puerperal women with diabetes.
During the period of pregnancy and lactation, different physiological mechanisms are involved with the adequate supply of vitamin A between mother and child. However, the mechanisms responsible for the transfer of ingested vitamin destined to the mammary gland and its subsequent secretion into the breast milk are not fully elucidated in humans.

In animal experiments, said transfer can occur through the complex RBP-retinol or chylomicrons (Green et al. 2001). Although the literature shows controversial information on the change of serum RBP in the presence of gestational diabetes, it is noticed that the milk retinol does not seem to be altered. Whereas the complex (RBP-retinol) in the fasting state is responsible for about $90 \%$ of retinol 
in blood levels (Bellovino et al. 2003), it is possible to suggest that there are compensatory mechanisms that assist in the passage of retinol to the mammary gland, favoring the children.

The serum retinol found in the healthy group showed analogy to Ribeiro et al. (2010) and Rodríguez et al. (2002) findings. There was no statistical difference between this group and the patients with diabetes in this study. Studies in pregnant women with gestational diabetes also found no change in serum retinol (Grissa et al. 2007, Tepper et al. 2010) nor in RBP4 (Khovidhunkit et al. 2012).

By analyzing puerperal women with diabetes in the postpartum period, Ribeiro et al. (2011) found reduced levels of serum retinol, suggesting that the alteration of insulin secretion would influence serum concentrations of RBP and consequently in retinol, since the metabolism of this vitamin would be related to beta cell function. The sample size may have been a factor influencing the discrepancy of findings between this study and the previously mentioned (16 individuals).

In the third trimester, a resistance to insulin occurs naturally, with a reduction of approximately $50 \%$ of the sensitivity to this hormone, and in the postpartum period that resistance decreases, possibly influenced by placental hormones (Buchanan et al. 2007). Saucedo et al. (2011) analyzed the insulin resistance (HOMA-IR), serum insulin of fasting and RBP-4 during pregnancy (30th week) and in the postpartum period (6th week) and verified that the insulin levels and RBP-4 decreased significantly after childbirth in healthy women, strengthening the hypothesis of the influence of placental hormones during healthy pregnancy, however, no significant change for women with diabetes was found.

Evidence suggests that RBP4 levels are elevated in patients with diabetes and would be responsible for the interruption of insulin signaling in muscle tissue (Yang et al. 2005), by reducing the phosphatidylinositol 3-kinase (PI 3-kinase) and the subsequent phosphorylation of the insulin receptor substrate-1 (IRS-1). In the liver RBP4 would not affect the PI 3-kinase, but instead would increase the expression of the enzyme phosphoenol pyruvate carboxykinase (PEPCK), resulting in increased hepatic production of glucose, influencing blood glucose homeostasis (Wolf 2007).

This study take place occasionally in the immediate postpartum period and the individual assessment of puerperal women demonstrates that there is a greater tendency of patients with diabetes to vitamin A deficiency. Therefore, possibly in a longitudinal study, the cases of this deficiency could be more evident and the reduction would also be significant.

Although no difference was found in the concentration of serum retinol and colostrum from healthy women and women with gestational diabetes, it was observed that women with diabetes have a higher probability of having hypovitaminosis A.

\section{ACKNOWLEDGMENTS}

The authors thank the mothers who agreed to participate in this study, Conselho Nacional de Desenvolvimento Científico e Tecnológico (CNPq), Postgraduate Program in Biochemistry and Molecular Biology at the Federal University of Rio Grande do Norte and Januário Cicco Maternity School.

\section{RESUMO}

Foi verificada a influência do diabetes gestacional sobre deficiência de vitamina A em puérperas e, consequentemente, em seus recém-nascidos, por meio de um estudo caso-controle do tipo transversal realizado com puérperas voluntárias. O grupo controle foi composto por mulheres saudáveis e o grupo caso foi composto por mulheres com diabetes gestacional. Cento e sete mulheres foram recrutadas, correspondendo a 71 controles e 36 casos. Dados pessoais, gestacionais e dos recém-nascidos foram coletados diretamente dos prontuários médicos durante a internação. O retinol foi determinado no colostro e no soro 
por Cromatografia Líquida de Alta Eficiência. As puérperas com diabetes gestacional eram mais velhas, tinham mais filhos e maior prevalência de parto por cesariana. Não houve diferença na concentração de retinol no leite e soro maternos entre os grupos. No entanto, observou-se que $16,7 \%$ das pacientes do grupo com diabetes tinham deficiência de vitamina $\mathrm{A}$ e apenas $4,1 \%$ tinham essa deficiência no grupo de controle. Embora não tenha sido encontrada diferença na concentração de retinol sérico e no colostro entre mulheres com e sem diabetes gestacional, a análise individual mostra que aquelas com diabetes têm um risco maior de serem deficientes em vitamina $\mathrm{A}$.

Palavras-chave: colostro, Diabetes gestacional, CLAE, Hipovitaminose A, Pós-parto.

\section{REFERENCES}

BASU TK AND BASUALdo C. 1997. Vitamin A homeostasis and diabetes mellitus. Nutrition 13: 804-806.

Bellovino D, Apreda M, Gragnoli S, Massimi M AND GAETANI S. 2003. Vitamin A transport: in vitro models for the study of RBP secretion. Mol Aspects Med 24: 411-420.

Buchanan TA, Xiang A, KJos SL And Watanabe R. 2007. What is gestational diabetes? Diabetes Care 30: 105-111.

Chan TF, Chen HS, Chen YC, LeE CH, CHOU FH, CHEN IJ, CHEN SY, JONG SB AND TSAI EM. 2007. Increased serum retinol-binding protein 4 concentrations in women with gestational diabetes mellitus. Reprod Sci 14: 169-174.

COHEN J. 1988. Statistical power analysis for the behavioral sciences, $2^{\text {nd }}$ ed., Hillsdale, New Jersey: Lawrence Erlbaum Associates, $567 \mathrm{p}$.

Debier C And Larondelle Y. 2005. Vitamins A and E: metabolism, roles and transfer to offspring. Br J Nutr 93: 153-174.

ERIKSTRUP C ET AL. 2009. RBP-to-retinol ratio, but not total $\mathrm{RBP}$, is elevated in patients with type 2 diabetes. Diabetes Obes Metab 11: 204-212.

GiUliano AR, Neilson EM, Kelly BE AND CANField LM. 1992. Simultaneous quantitation and separation of carotenoids and retinol in human milk by highperformance liquid chromatography. Methods Enzymol 213: 391-399.

GolBert A AND CAMPos MAA. 2008. Diabetes mellito tipo 1 e gestação. Arq Bras Endrocrinol Metab 52: 307-314.

Green MH, Green JB, AKohoue SA AND Kelley SK. 2001. Vitamin A intake affects the contribution of chylomicrons vs retinol-binding protein to milk vitamin A in lactating rats. J Nutr 131: 1279-1282.

GRISSA O ET AL. 2007. Antioxidant status and circulating lipids are altered in human gestational diabetes and macrosomia. Transl Res 150: 164-171.
HARRISON EH. 2005. Mechanisms of digestion and absorption of dietary vitamin A. Annu Rev Nutr 25: 87-103.

Khovidhunkit W, PRUKSAKorn P, Plengpanich W AND THARAVANIJ T. 2012. Retinol-binding protein 4 is not associated with insulin resistance in pregnancy. Metabolism 61: 65-69.

KRZYZANOWSKAK, ZEMANY L, KRUGLUGER W, SCHERNTHANER GH, MitTermayer F, SCHNACK C, RAHMAN R, BRIX J, KAHN BB AND Schernthaner G. 2008. Serum concentrations of retinol-binding protein 4 in women with and without gestational diabetes. Diabetologia 51: 1115-1122.

LiRA LQ AND DimensteIn R. 2010. Vitamina A e diabetes gestacional. Rev Assoc Med Bras 56: 355-359.

MetZGER BE ET AL. 2007. Summary and recommendations of the fifth international workshop-conference on gestational diabetes mellitus. Diabetes Care 30: 251-260.

MinistÉRIO DA SAÚDE. 2010. Brasil. Secretaria de Atenção à Saúde. Departamento de Ações Programáticas e Estratégicas. Gestação de Alto Risco: Manual Técnico. $5^{\mathrm{a}}$ edição, Brasília, 302 p.

Nierenberg DW AND NANN SL. 1992. A method for determining concentrations of retinol, tocopherol, and five carotenoids in human plasma and simple tissue. Am J Clin Nutr 56: 417-426.

RAMAKRISHNAN U. 2002. Prevalence of micronutrient malnutrition worldwide. Nutr Rev 60: S46-52.

Rhee E AND PlutzKy J. 2012. Retinoid metabolism and diabetes mellitus. Diabetes Metab J 36: 167-180.

RiBEIRO KDS, ARAÚJO KF AND DiMENSTEIN R. 2009. Efeito da suplementação com vitamina A sobre a concentração de retinol no colostro de mulheres atendidas em uma maternidade pública. Rev Assoc Med Bras 55: 452-457.

Ribeiro KDS, AraúJo KF, SOUZA HH, SOARES FB, PEREIRA MC AND DIMENSTEIN R. 2010. Nutritional vitamin A status in northeast brazilian lactating mothers. J Human Nutr Diet 23: 154-161.

RIBEIRO PPC, LIRA LQ AND DIMENSTEIN R. 2011. Análise da concentração de retinol sérico em lactantes com e sem diabetes mellitus gestacional atendidas em uma maternidade pública da cidade de Natal, Estado do Rio Grande do Norte, Brasil. Rev Pan-Amaz Saude 1: 67-71.

Rodríguez GP, Alonso DP, Sintes GS, MATOS CM, HERNÁNDEZ AC, ENRÍQUEZ YR AND GUTIÉRREZ PM. 2002. Vitaminas antioxidantes em um grupo de embarazadas y recién nacidos durante un año de estudio. Rev Cubana Aliment Nutr 16: 85-94.

Saucedo R, Zarate A, Basurto L, Hernandez M, Puello E, GALVAN R AND CAMPOS S. 2011. Relationship between circulating adipokines and insulin resistance during pregnancy and postpartum in women with gestational diabetes. Arch Med Res 42: 318-323.

SociedAdE BRAsiLEIRA DE DiABETES. 2009. Brasil. Diretrizes da Sociedade Brasileira de Diabetes. Itapevi, SP: A Araújo Silva Farmacêutica, 329 p.

SUSKIND DL. 2009. Nutritional deficiencies during normal growth. Pediatr Clin North Am 56: 1035-1053. 
SZLAGATYS-SIDORKIEWICZ A, ZAGIERSKI M, JANKOWSKA A, ŁUCZAK G, MACUR K, BĄCZEK T, KORZON M, KRZYKOWSKI G, MARTYSIAK-ŻUROWSKA D AND KAMIŃSKA B. 2012. Longitudinal study of vitamins A, $\mathrm{E}$ and lipid oxidative damage in human milk throughout lactation. Early Hum Dev 88: 421-424.

Tepper BJ, Kim YK, Shete V, Shabrova E AND QuAdro L. 2010. Serum retinol-binding protein 4 (RBP 4) and retinol in a cohort of borderline obese women with and without gestational diabetes. Clin Biochem 43: 320-323.

WOLF G. 2007. Serum retinol-binding protein: a link between obesity, insulin resistance, and type 2 diabetes. Nutr Rev 65: $251-256$
WORLD HEALTH ORGANIZATION. 1996. Indicators for assessing vitamin A deficiency and their application in monitoring and evaluating intervention programs. Geneva: World Health Organization, $66 \mathrm{p}$.

Yang Q, Graham TE, Mody N, Preitner F, Peroni OD, ZABOLOTNY JM, KotANI K, QUADRO L AND KaHN BB. 2005. Serum retinol binding protein 4 contributes to insulin resistance in obesity and type 2 diabetes. Nature 436: 356-362. 